Florida International University FIU Digital Commons

4-6-1994

\title{
Correlates of union and organizational commitment : a survey of former Eastern Airlines employees
}

Sharon A. Israel Dolfi

Florida International University

DOI: $10.25148 /$ etd.FI15101209

Follow this and additional works at: https://digitalcommons.fiu.edu/etd

Part of the Psychology Commons

\section{Recommended Citation}

Dolfi, Sharon A. Israel, "Correlates of union and organizational commitment : a survey of former Eastern Airlines employees" (1994). FIU Electronic Theses and Dissertations. 3072.

https://digitalcommons.fiu.edu/etd/3072 
FLORIDA INTERNATIONAL UNIVERSITY

Miami, Florida

CORRELATES OF UNION AND ORGANIZATIONAL COMMITMENT: A SURVEY OF FORMER EASTERN AIRLINES EMPLOYEES

A thesis submitted in partial satisfaction of the requirements for the degree of

MASTER OF SCIENCE

IN

PSYCHOLOGY

by

Sharon A. Israel Dolfi

1994 
To: Arthur W. Herriott College of Arts and Sciences

This thesis, written by Sharon A. Israel Dolfi, and entitled CORRELATES OF UNION AND ORGANIZATIONAL COMMITMENT: A SURVEY OF FORMER EASTERN AIRLINES EMPLOYEES, having been approved in respect to style and intellectual content, is referred to you for judgment.

We have read this thesis and recommend that it be approved.

Gary Moran

Juan Sanchez

Scott Fraser, Major Professor

Date of Defense: April 6, 1994

The thesis of Sharon A. Israel Dolfi is approved.

Dean Arthur W. Herriott College of Arts and Sciences

Dr. Richard L. Campbell

Dean of Graduate Studies

Florida International University, 1994 
C COPYRIGHT 1994 BY Sharon A. Israel Dolfi

All rights reserved 


\section{ACKNOWLEDGMENTS}

I express sincerest gratitude to my advisor, Dr. Scott Fraser, for his tremendous assistance in the preparation of this thesis.

I thank my Committee members, Dr. Juan Sanchez and Dr. Gary Moran, for their very beneficial suggestions, advice, and comments.

I thank Ms. Susan Russell and Ms. Mary Jane Barry for their immeasurable help in locating individuals for participation and distributing surveys.

To the former employees of Eastern Airlines, I offer thanks for sharing their thoughts and feelings, and my best wishes always.

Finally, I thank my family and friends for their ever-present encouragement and support. 


\author{
ABSTRACT OF THE THESIS \\ CORRELATES OF UNION AND ORGANIZATIONAL COMMITMENT: \\ A SURVEY OF FORMER EASTERN AIRLINES EMPLOYEES \\ by \\ Sharon A. Israel Dolfi \\ Florida International University, 1994 \\ Miami, Florida \\ Professor Scott Fraser, Major Professor
}

Former Eastern Airlines flight attendants were surveyed regarding their levels of union, organizational, and dual commitment, union participation, strike participation and support, and current feelings of job stress, job affect and job satisfaction. It was found that union commitment was positively correlated with union participation. Due to the unique situation at Eastern, it was also found that there was no difference in levels of strike participation and support between those dually committed and those unilaterally committed to the union. Strike participation and support also correlated positively with one measure of current job stress. Other findings included a positive correlation between job affect and satisfaction, and a negative correlation between both of these measures and job stress. 
ACKNOWLEDGMENTS...................... iv

ABSTRACT $\ldots \ldots \ldots \ldots \ldots \ldots \ldots \ldots \ldots \ldots \ldots \ldots \ldots \ldots \ldots$

TABLE OF CONTENTS........................ vi

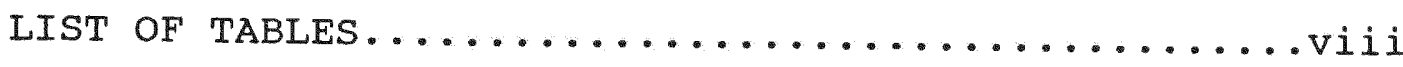

CHAPTER

I. INTRODUCTION. ........................

II. REVIEW OF THE LITERATURE................ 2

Union, Organizational and Dual Commitment..... 2

Union Commitment and Participation............. 3

Union/Company/Dual Commitment and Participation. 5

The Eastern Situation.................. 9

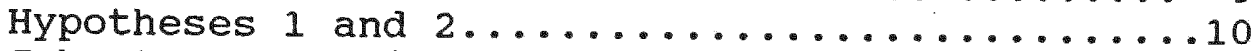

Job Stress/Strain, Control and Learned

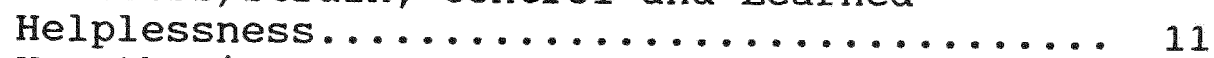

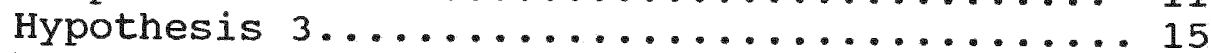

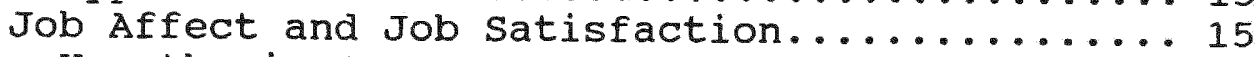

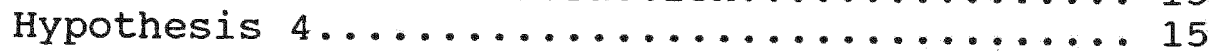

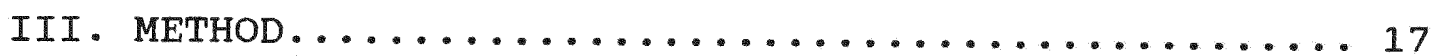

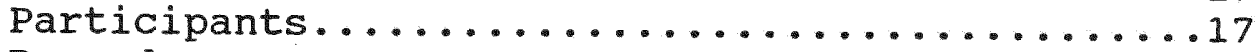

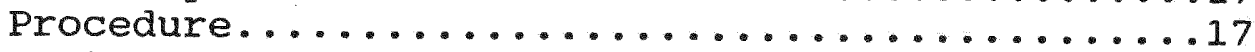

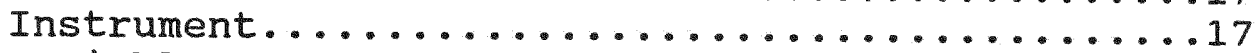

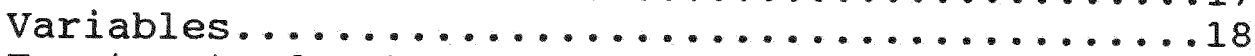

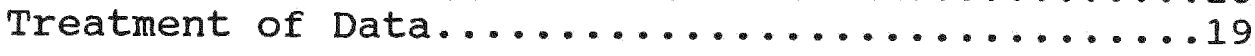

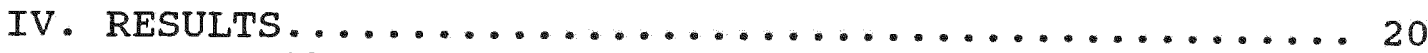

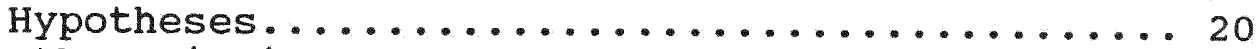

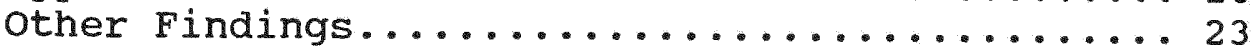

V. DISCUSSION............................ 24

Interpretations and Implications......... 24

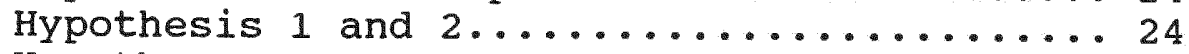

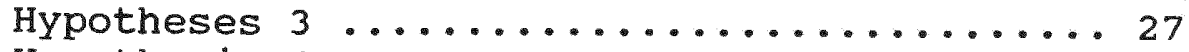

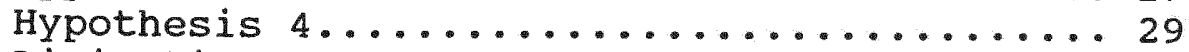

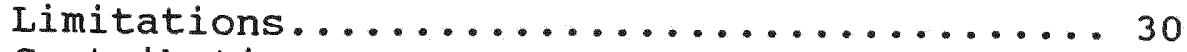

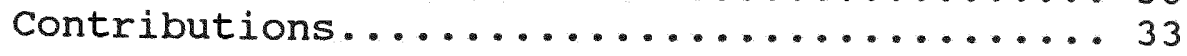

LIST OF REFERENCES............................. 34 


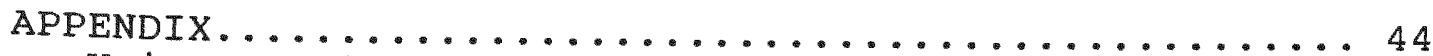

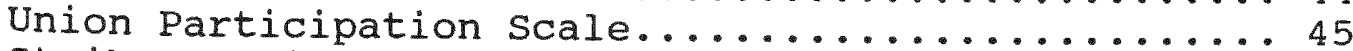

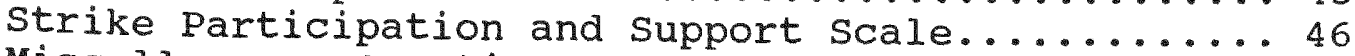

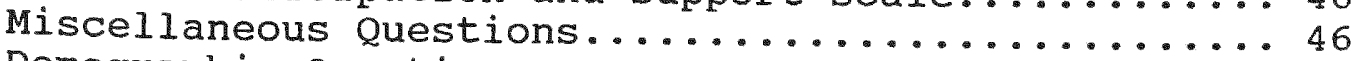

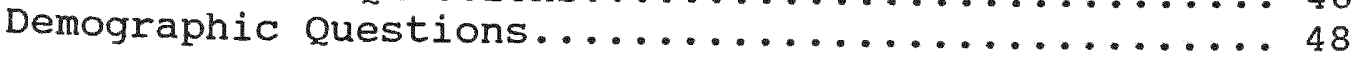




\section{LIST OF TABLES}

TABLE

PAGE

1. Correlation Matrix.................... 20

2. Multiple Regression Analysis Predicting Strike

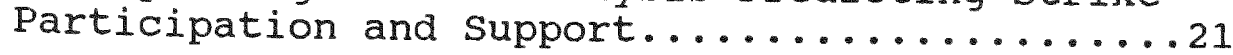


CHAPTER I

INTRODUCTION

On January 18, 1991, Eastern Airlines closed their operations, ending a long, protracted struggle for survival highlighted by a March, 1989 labor strike involving all three of the company's primary labor unions: the International Association of Machinists (IAM), the Transit Workers Union (TWU), and the Airline Pilots Association (ALPA). As unfortunate as the situation was (and continues to be for those left unemployed), it is, nonetheless, clear that an analysis of the attitudes and feelings of those involved in such an intense, and ultimately futile, dispute would contribute to our knowledge of the dynamics of laborintensive business operations. With the participation of former Eastern flight attendants, the present study focuses on union and organizational commitment, union participation, strike participation and support, job stress, job affect, and job satisfaction. 


\section{CHAPTER II}

\section{REVIEW OF THE LITERATURE}

\section{Union, Organizational, and Dual Commitment}

Union commitment on the part of those represented is the backbone of union survival, and as such, has been studied quite extensively (Friedman \& Harvey, 1986; Fullagar, 1986; Gordon, Philpot, Burt, Thompson, \& Spiller, 1980; Klandermans, 1989; Ladd, Gordon, Beauvais, \& Morgan, 1982; Mellor, 1990; Tetrick, Thacker, \& Fields, 1989; Thacker, Fields, \& Barclay, 1990; Thacker, Fields, \& Tetrick, 1989). Organizational, or company, commitment, often viewed as the polar opposite of union commitment, has been utilized as both a source of comparison (Angle \& Perry, 1986; Barling, Wade, \& Fullagar, 1990; Blyton, Nicholson, \& Ursell, 1981; Conlon \& Gallagher, 1987; Fukami \& Larson, 1984), and a variable in its own right (Decotiis \& Summers, 1987; McGee \& Ford, 1987; Porter \& Smith, 1970 Porter, Steers, Mowday, \& Boulian, 1974; Williams \& Hazer, 1986). Although seemingly contradictory, they are not mutually exclusive attitudes. This realization has led to the additional study of dual commitment.

The following paragraphs review relevant studies regarding union, organizational and dual commitment, and how they relate to participation. This discussion will be followed by a description of how the present study 
contributes to this body of research. The literature reviewed will be used to develop hypotheses regarding the former Eastern employees' levels of union, organizational, and dual commitment, and union and strike participation and support.

\section{Union Commitment and Participation}

The four classic components of union commitment, union loyalty, responsibility to the union, willingness to work for the union, and belief in unionism, (Gordon et al., 1980) have individual and shared antecedents and outcomes (Thacker, Fields \& Barclay, 1990). Antecedents include past fulfillment of the union's missions and accessibility of union officers. Outcomes are both "behavioral" (i.e., attendance at union meetings) and "attitudinal" (i.e., supporting the union's political action) (p.33).

The union commitment/participation literature deals with many areas, including reasons for joining and participating, components and correlates of commitment, and postulated models explaining both types of behavior. Beutell and Biggs (1984) found two common factors to be strongly (positively) related to intentions to join a union: "the instrumentality of intrinsic outcomes," and "the valence of extrinsic outcomes" (p.215). Intrinsic outcomes were personal advantages (growth and accomplishment) felt to be gained by joining a union, 
while extrinsic outcomes included such variables as pay and job security. Union loyalty has been shown to be significantly related to formal union participation, such as voting in union elections and knowledge of the union contract (Fullagar \& Barling, 1989). Perceived union instrumentality moderated (strengthened) this relationship.

Mellor (1990) found that level of union commitment was positively correlated with percentage of membership decline in the locals; those unions in trouble had more committed members. These locals also reported more willingness to participate in future strike activity. Their threatened identity would cause the members to increase their survival efforts, supporting the union in any way needed. The affective component of union commitment has also been demonstrated (Schriesheim, 1978). Subjects exhibited a very strong relationship between positive union attitudes and actual pro-union voting in the past. Even so, these correlations were still less than the even stronger negative relationship between pro-union voting and economic satisfactions. In an attempt to create a "comprehensive model of union voting behavior" $(p .643)$ in certification and decertification elections, Summers, Betton, and Decotiis (1986) included all of the following variables which contribute to individual beliefs and attitudes: work 
context, desire for change, balance between union and organizational instrumentality, election campaigns, employer coercion, and group influences. Klandermans (1984, 1986) also discussed a model that can be applied to union participation: expectancy-value theory, which explains that "willingness to participate is a function of perceived costs and benefits" (p.583). Three areas were identified in which expectancy-theory operated for decision-making: collective motives (for the collective good of the workers), social motives (which included consideration of family and colleagues), and reward motives (financial and career-wise).

In summary, the union commitment/participation literature shows the strong connection between attitudinal commitment and formal participation. The present study tested this relationship both before and during a very long and bitter strike, which eventually resulted in the loss of thousands of jobs and years of company tenure.

The next section reviews literature pertaining to dual (union and organizational) commitment, and its relationship to participation.

Union/Company/Dual commitment and Participation Although organizational commitment scales have been used to assess both union and company commitment, the two types are inherently different and should be measured 
separately (Barling et al., 1990). Fukami and Larson (1984) also found this need for separation, but found evidence, too, for the concept of dual loyalty. Work experiences (pay equity, supervisory relations, and social involvement) related to both types of commitment, prefacing their suggestion that "a positive relationship between company commitment and union commitment may be explained in terms of the day-to-day experiences on the job, even if other variables [personal and role-related] account for more of the variance in company commitment" $(p .371)$.

Several recent articles provide interesting observations about the role of dual commitment and satisfaction, as well as the relationship between union and company commitment. Conlon and Gallagher (1987) found that union commitment was higher for union members than for either former members, or for those who never joined the union. Interestingly, however, those who left the union evidenced the lowest level of both union commitment and company commitment. Furthermore, members and never-members reported the same amount of company commitment.

Using exchange theory as explanation, Magenau, Martin, and Peterson (1988) found three indicators of dual commitment: positive union-decision making (related to a satisfying exchange with the union), job 
satisfaction (satisfying exchange with the company), and positive union-management relations (satisfying exchange with both organizations). Also, union stewards reported higher levels of dual commitment than rank-and-file union members.) Although it appears that different variables often predict union vs. company satisfaction, the underlying reason for both may be the need for justice (Fryxell \& Gordon, 1989). They found that the way in which grievances were handled (not necessarily the outcomes) best predicted satisfaction with unions, while the "belief in a moral order" (p.851) at work (rather than the satisfaction of lower-order needs such as wages and benefits) best predicted satisfaction with management.

Blyton et al. (1981) found that higher status employees often showed higher levels of union participation in certain areas, such as attending meetings and voting, than did low status employees. The authors claimed that the results were congruent with the idea that union participation actually reflects workrelated commitment, and is also congruent with the "common and long-standing feature" (p.42) of dual commitment among management employees involved in "national level union management" (even among high-level managers). Angle and Perry (1986) found that dual commitment was higher in organizations with better labor- 
management relations and that self-reported union participation moderated the relationship (made stronger for active participants, made weaker for the less active). They explained that any perceived incompatibility between union and company is made more salient through union participation, pulling those in the less-cooperative situations toward less dual commitment; those in cooperative situations, however, are not faced with the dilemma of choice.

Relevant to the study of strike participation and support, Stagner and Eflal (1982) surveyed attitudes before, during, and after an automobile company strike. Dissonance theory was used to explain that, during the strike, union members tended to both become more militant against their employer, and to evaluate the union leadership more favorably. The strengthening of these beliefs would reduce dissonance, and serve to justify the actions they took and hardships they endured during the strike. A further face valid hypothesis (that greater "intraunion cohesion" ( $p .37$ ) would be evident during the strike) was not confirmed.

In summary, the dual commitment literature makes a convincing argument for its existence as a viable alternative to choosing between union and employer. There exists a lack of information, however, on the comparison between those unilaterally committed to one or 
the other side, versus those dually committed. Also, there are few studies regarding actual strikes, and none were found concerning commitment and actual strike participation. The present research grants further insight into these areas, while also studying the unique situation at Eastern Airlines.

The next section describes this unique situation, and how an analysis of it led to the first set of hypotheses.

\section{The Eastern Situation}

It is, perhaps, a common assumption that unions involved in a labor strike are militant against the company, its management, and everything for which those two entities stand. Those who struck at Eastern, however, continuously held on to the feeling of being part of the "Eastern family of employees," and, to hopes (along with members of management) that a buyer group would step in and save the airline (Owens, McNair, \& Lopez, 1991; Reed, 1991). Indeed, for most of the striking workers, the strike was not against Eastern, but rather against Eastern's Chairman Frank Lorenzo, and what they felt to be his goal of Eastern's destruction (Chrissos, 1989; Lyons, 1989). Newspaper articles continuously showed and described pictures of strikers with Lorenzo's name with a line through it, and such statements as "Just Say No to Lorenzo," and "Eastern Yes, 
Lorenzo No" (Pauly, Calonius \& Waldman, 1989; Schwartz, Calonius, Gonzalez \& Gibney, Jr., 1989).

Thus, since the strikers did so for the good of the airline, it is likely that many of these people also held high levels of dual commitment. However, consistent with the literature, we expected to find a positive correlation between union commitment and union participation.

In summary, the present research analyzed actual strike participation in relation to commitment, an area that has not been studied before. In addition, it focused on a most notorious and unique (as described above) labor strike.

\section{Hypotheses 1 and 2}

The hypotheses tested were as follows:

Hypothesis 1: Union commitment will positively correlate with union participation. However, due to the unique strike attitude/reasoning that prevailed (as described above), it was further predicted that:

Hypothesis 2: Organizational commitment will not moderate the relationship between union commitment and strike participation and support.

(In other words, there will be no difference expected between those dually committed and those unilaterally union-committed, in their levels of strike participation and support.) 
The next section describes the relationship between job stress and both control and learned helplessness, and how this was applied to the Eastern situation. A summation leads to the second set of hypotheses.

Job Stress/Strain, Control, and Learned Helplessness

Although there is little job stress literature pertaining to either commitment or participation, both of these areas deal with issues of control, a topic extensively covered in the job stress literature (below). It is likely that control was an integral part of strike participation and support at Eastern. Those who were committed to the union and the strike, and participated in the strike, felt powerful when the strike began and caused havoc in the company (Fields, 1989; "Union Solidarity," 1989). Ultimately, however, they realized they could not prevent the closure of their company, and the focus became the "tragedy" (p.4A, col.2) that had befallen the airline (Reed, 1991). Similarly, the learned helplessness (Overmier \& Seligman, 1967) model as applied to humans might explain that the closure of the airline during the strike (and the accompanying feelings of helplessness) would "[transfer] to new situations" (Greer \& Wethered, 1984, p.525) and perpetuate continuing feelings of despair and stress. Below is a review of the occupational stress/control and learned helplessness studies. It will be followed by discussion regarding its 
relationship to the present study.

It is important to preface the job stress discussion with a clarification of terms. Jex, Beehr, and Roberts (1992) found that, although "researchers were more likely to use the word 'stress' to mean 'stressor,' an analysis of survey respondents showed "stress" to correlate more strongly with "strains" (p.627). This is relevant to the present research because although the term "stress" is utilized, the actual survey items measure both types of outcome, psychological stress and physiological strain. Much of the literature related to job stress and control is characterized by internal-external locus of control (LOC) studies and articles. Nelson and Quick's (1985) model found internal control (and the inclusive idea of self-determined destiny) to purportedly help female executive to "facilitate beneficial outcomes from stress," (p.213) making the situation work in her own favor. Jenner (1988) found evidence that an external locus of control (belief in the influence of powerful others) was positively related to work stress, but not stress at home. Results of another study showed that external LOC police officers and firefighters demonstrated a positive relationship between conflict and strain, whereas no such relationship was reported for internal LOC officers and firefighters (Fusilier, Ganster, \& Mayes, 1987). The external individuals also 
reported more health problems. Dailey, Ickinger, and Coote (1986) found similar evidence: experienced stress symptoms, such as insomnia and digestive problems, were related to externality in three individual samples.

Tetrick and LaRocco (1987) tested an existing model (Sutton \& Kahn, 1986) of the relation of understanding, prediction, and control to work-related stress. All three variables were negatively correlated with perceived stress, while understanding and control moderated the relationship between perceived stress and satisfaction. Chemers, Hays, Rhodewalt, and Wysocki (1985) tested Fiedler's (1967) contingency model of leadership in the area of job stress, with results indicating that those whose leadership style and "level of situational control" (p.628) matched were less affected by job stress.

A simple linkage of lack of control and the experience of job stress was explored by Ackerley, Burnel1, Holder, and Kurdek (1988), finding that the "modal burned-out clinician" $(\mathrm{p} .624)$ felt a lack of control in therapeutic sessions. Walker, Walker, and MacLennan (1986) interviewed farmers and their spouses about apparent "chronically high" job stress (p.427). Although government policy, weather, and market conditions were all included as causing job stress, perceived lack of control over such phenomena was, also, often specifically mentioned as a major contributor to 
feelings of stress.

Several articles have applied the model of learned helplessness to stress/strain in the workplace. Arnhold and Razak (1991) explore the need to deal with learned helplessness in the workplace of the 1990's as workplace demographics change and the demand for increased skill rises. The suggestion is made that what once may have been thought of as "personal problems" (p.105) need to be addressed to help employees, and ultimately businesses, succeed. Wood (1989) found that the learned helplessness phenomenon ("repeated life experiences [being interpreted] by people to be an indication that they are not in control of their own fate") (p.4) is a key element as to whether displaced homemakers are successful in entering the marketplace.

"Burnout" was found to relate to learned helplessness and the importance of setting attainable goals (Greer \& Wethered, 1984), as well as to learned helplessness as a somewhat stable personality factor (McMullen \& Krantz, 1988). In a reformulation of the original model, Seligman and Schulman (1986), found that quitting, when difficulties are encountered, is more likely for those with a "pessimistic explanatory style" (p.832). On the other hand, linkage has also been made between becoming unemployed (not of one's own accord) and feelings of learned helplessness (Baum, Fleming, \& Reddy, 
1986). The authors discussed the role of

"noncontingency" (p.515) (in unsuccessfully searching for work) and its ability to increase learned helplessness.

Thus, lack of control and learned helplessness have been demonstrated to be related to job stress/strain. There is, however, a lack of research on the later effects of an acutely stressful time-period, and as before, little data available on real labor strikes. As previously described, the decline and ultimate closure during the strike left its employees with feelings of lack of control and learned helplessness in employment. It is, therefore, likely, that their level of strike participation and support would be related to current feelings of job stress/strain. This led to the next hypothesis tested.

Hypothesis 3: Strike participation and support will positively correlate with current job stress. Job Affect and Job Satisfaction

Based upon the positive relationship between job affect and job satisfaction (Brief \& Roberson, 1989) and the negative relationship between job satisfaction and job stress (Kremer, Fraser \& Henzman, 1987; Cummins, 1989), the following hypothesis was tested as an extension of Hypothesis 3:

Hypothesis 4: Strike participation and support will negatively correlate with current job affect and current 
job satisfaction. 


\section{CHAPTER III \\ METHOD \\ Participants}

Participants were 116 former Eastern Airlines flight attendants, represented by the TWU (Transit Workers Union) collective bargaining unit.

\section{Procedure}

Explanatory letters, questionnaires, and stamped return envelopes were mailed or personally given to the participants during 1993. The questionnaires were anonymous.

\section{Instrument}

The following measures were utilized:

Participants were asked to respond to the following scales in regard to their experience at Eastern Airlines: 1) Union Commitment: 29-item scale (Tetrick et al., 1989) based on original scale (Gordon et al., 1980).

2) Organizational Commitment: 15-item scale - Porter and Smith (1970).

3) Dual Commitment and Unilateral Union Commitment: Was derived from an analysis of union and organizational commitment.

4) Union Participation: 8-item scale derived from Fullagar (1986), Angle and Perry (1986), with 2 additional items added; see Appendix.

5) Strike Participation and Support: A 6-item scale 
developed for this study; see Appendix.

Participants were asked to respond to the following scales in regard to their present situation. Those who remain unemployed, therefore, did not respond to the Job Stress or Job Satisfaction scales, and were asked to respond to the Job Affect Scale in regard to their feelings toward work in general:

6) Job Stress: 30-item scale from Quinn and Shepard's (1974) Depressed Mood at Work scale, Patchen's (1970) Psychological symptoms of Stress scale and House and Rizzo's (1972) Anxiety-Stress Questionnaire.

7) Job Affect: 20-item scale - Brief, Burke, George, Robinson and Webster (1988).

8) Job Satisfaction: 25-item scale: Affective Responses portion of the Job Diagnostic Survey (JDS) (Hackman and Oldham, 1975).

9) Miscellaneous Questions: see Appendix.

10) Demographic Questions: see Appendix.

\section{Variables}

In Hypothesis 1, the predictor variable was union commitment, and the criterion variable was union participation. In Hypothesis 2 , the independent variables were dual commitment, unilateral union commitment, and unilateral organizational commitment, and the dependent variable was strike participation and support. In Hypotheses 3 and 4 , the predictor variables 
were strike participation and support. The criterion variable in Hypothesis 3 was job stress. In Hypothesis 4, the criterion variables were job affect and job satisfaction.

\section{Treatment of Data}

SPSS was used for the statistical analyses. Correlation coefficients were calculated for the relationships between commitment, participation, job affect, job satisfaction, and job stress. Multiple regression was utilized to test the relationship between commitment and strike participation and support for Hypothesis 2. A power analysis was conducted to determine the strength of the regression equation. 
CHAPTER IV

RESULTS

Hypotheses

Hypotheses 1 and 2

Table 1 displays the matrix of Pearson correlation coefficients for all of the major response variables. Hypothesis 1 was supported; the correlation of union commitment and union participation was significant at the .001 level $(\underline{x}=.76)$. Table 2 presents the multiple regression analysis performed which supported Hypothesis 2. As shown, only union commitment contributed ( $\underline{R}$ squared $=.61$ ) to the equation in predicting strike participation and support (beta weight $=.78, \mathrm{p}<.001$ ). Organizational commitment did not contribute to the equation (beta weight $=-.01$ ). Furthermore, for a multiple regression analysis with two independent variables and 115 cases, statistical power was found to be greater than .80 for a small effect size (R-squared = .20) as defined by Cohen (1969).

Hypotheses 3 and 4

The overall stress scale did not significantly correlate with strike participation and support. One of the stress subscales (Depressed Mood at Work (Quinn and Shepard, 1974) was, however, positively correlated ( $\mathrm{p}<$ .05) with strike participation and support, supporting Hypothesis 3. (The other stress subscales were Patchen's 
Table 1

Correlation Matrix

UC UP $S P$ OC JA JS $S T$ DM PS

$\mathrm{UC}$

.76
$* *$

$\begin{array}{rr}.78 & .58 \\ * * & * *\end{array}$

OC $\quad .00 \quad .15 \quad-.01$

JA $\quad-.01-.10 \quad-.11 \quad .16$

JS $\quad \begin{array}{lllll}.03 & -.01 & -.07 & .03 & .52 \\ & & & & .03\end{array}$

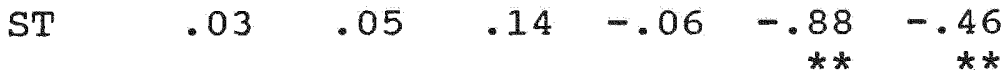

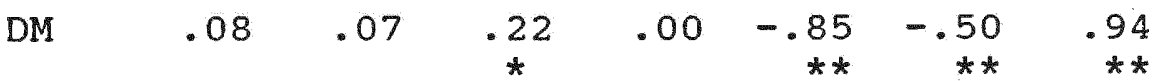

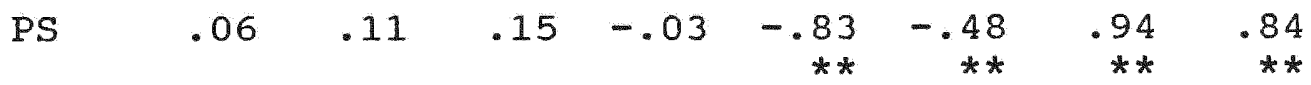

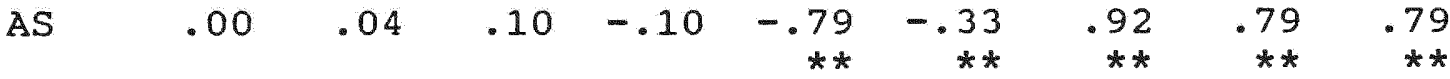

$\begin{array}{lrrrrrrrrrr}\text { Mean } & 3.66 & 3.38 & 3.46 & 4.62 & 3.70 & 5.44 & -.02 & 1.86 & 2.67 & 1.29 \\ \mathrm{SD} & .81 & .82 & 1.06 & 1.22 & .85 & 1.16 & .93 & .70 & 1.30 & .22 \\ \mathrm{n} & 116 & 116 & 116 & 115 & 115 & 102 & 102 & 102 & 103 & 102\end{array}$

* $\mathrm{p} \leq .05$

$* * \quad \mathrm{p} \leq .001$

UC - Union Commitment

UP - Union Participation

SP - Strike Participation

OC - Organizational Commitment

JA - Job Affect

JS - Job Satisfaction

ST - Stress (NOTE: Computed using z-scores; hence, the neg. mean)

DM - Depressed Mood at Work (Quinn and Shepard, 1974)

PS - Psychological symptoms of Stress (Patchen, 1970)

AS - Anxiety-Stress Questionnaire (House and Rizzo, 1972) 


\section{Table 2}

Multiple Regression Analysis Predicting Strike Participation and Support

Step Predictor Entered F-change df $\underline{R}$ Adj. R $\underline{R}$ Beta

$\begin{array}{llllllll}1 & \text { Union Commitment } & 156.87 & 1,102 & .61 & .60 & .61 & .78\end{array}$

2 Organizational $\quad \begin{array}{llllllll} & .03 & 2,101 & .61 & .60 & .00 & -.01\end{array}$ Commitment 
(1970) Psychological Symptoms of Stress and House and Rizzo's (1972) Anxiety-Stress Questionnaire.) Hypothesis 4 was not supported. Neither job affect nor job satisfaction correlated with strike participation and support.

\section{other Findings}

There were several other findings worthy of discussion. Union commitment and union participation were both positively correlated $(p<.001)$ with strike participation and support. Another strong positive correlation $(\underline{p}<.001)$ was found between job affect and job satisfaction. Furthermore, both job affect and job satisfaction were strongly negatively correlated ( $\underline{p}<$ $.001)$ with the stress scale and all of its components. Finally, the stress scale and its components all correlated very strongly (with coefficients between .79 and .94) with each other. 


\section{CHAPTER V}

\section{DISCUSSION}

The following discussion is structured around the results of each hypothesis tested. Each section, as well as a later summary, will describe the study's many contributions.

\section{Interpretations and Implications}

Hypotheses 1 and 2

Hypothesis 1: Union commitment will positively correlate with union participation.

Hypothesis 2: Organizational commitment will not moderate the relationship between union commitment and strike participation and support.

As was expected, union commitment correlated positively with union participation, supporting Hypothesis 1. The main finding though, in support of Hypothesis 2, was the lack of difference between those unilaterally union committed and those dually committed, versus those unilaterally management committed, in strike participation and support. These findings are particularly important because they add a new element to the strike/dual commitment literature: the comparison of dually and unilaterally committed strikers. To review some of the more relevant studies, Mellor (1990) found that higher levels of union commitment were found in locals in crisis situations, while Barling, wade and 
Fullagar (1990) found, in a sample of post-strikers, that totally different variables predict union and organizational commitment (which, therefore, should be measured separately). Fukami and Larson (1984) observed that only actual work experiences (pay equity, supervisory relations, and social involvement) were related to both types of commitment, while union members and "never-members" (Conlon \& Gallagher, 1987) have been shown to have equivalent levels of company commitment. The present study has brought these issues together (focusing on comparison of commitment type during a labor dispute) and demonstrated the lack of moderation on the part of organizational commitment in level of strike participation and support, due to the unique situation at Eastern Airlines.

The present results show that management and unions should realize that the reason for a strike may affect who will actively participate and support it; union commitment is not the only factor. This study, though, may be more far-reaching in regard to dual commitment and the actual role dual commitment plays in both the company and the union. The present research showed that individual dual commitment did not prevent employees from taking a firm union stand. Had it been previously known, this information might have helped the unions and management to reach a positive ending. Instead of 
remaining polarized, the "sides" could have better appreciated their differences and worked toward a solution. Other similar findings about the role dual commitment plays in labor-intensive businesses could only help to increase positive relations between the unions, management, and individual employees. In this case, those dually committed were no different than those unilaterally committed to the union in strike participation and support. Another question for future study would query what type of conditions would provide for the opposite: those dually committed to behave like those unilaterally committed to the organization. Similarly, one could study what type of unions/organizations (i.e., what industries, occupations) foster or interfere with dual commitment, and how that affects the parties involved. As an extension of the present research, it would be worthwhile to conduct a similar longitudinal study: before, during, and after a strike.

overall, the present findings illustrate the importance of dual commitment. Eastern Airlines was well known for its labor-management struggles and would not, seemingly, have been thought of as a "hotbed of dual commitment". The data, however, show otherwise. Dual commitment not only existed, but flourished, during a much-publicized bitter strike. 
As explained above, it is important for both management and unions to understand the existence of dual commitment in their own strategic efforts, and those on behalf of the employees. Both "sides" should realize that they are not, necessarily, in competition for employees' allegiance; employees can, and do, maintain support for both institutions. Employees, themselves, should also understand that dual commitment is not unusual; they can consider themselves supportive of both the company for which they work, and the union that represents them, and not feel as if they are being unfaithful to either one.

\section{Hypothesis 3}

Hypothesis 3: Strike participation and support will positively correlate with current job stress.

This hypothesis was partially supported; one stress sub-scale, Depressed Mood at Work, did demonstrate this correlation. Although the three stress subscales were highly correlated and thus acceptable to use in combination (Marino \& White, 1985), they do measure somewhat different kinds of stress. The Depressed Mood at Work scale (Quinn \& Shepard, 1974), focuses more on psychological stress (hopefulness, enjoying "things") than physiological stress. House and Rizzo's (1972) scale is the most physiological, while patchen's threequestion scale (though called "Psychological symptoms of 
Stress") asks about being "tired or worn out" in one question and "nervous, tense, or edgy" in another. Considering the time-lag between the participants' Eastern experience and their completion of the survey, it makes sense that present bodily experiences would be less related to commitment and participation of two years prior. This time difference may also attribute to the weakness of the only significant correlation found for this hypothesis.

It is logical that the most "straight forward" of the commitment and participation variables (strike participation and support) correlated with current job stress. Other variables were more general in nature, while strike participation described certain behaviors during a very circumscribed time-period. This timeperiod was the most recent, and arguably, the most memorable of their experience at Eastern. Those high in strike participation and support gained a great deal of control very quickly, maintained control while Eastern went into decline, and finally, completely lost control and their jobs. These feelings of lack of/loss of control and learned helplessness could easily affect their current feelings of job stress, particularly because $56 \%$ of those currently employed are still in the airline industry (most as flight attendants).

The current findings have implications for employees 
and management, and labor unions when involved. All should realize individuals' vulnerability to these phenomena (loss of control/learned helplessness) and their potentially debilitating, and long-term, effects. Management needs to be keenly aware of how organizational factors can affect their employees, and ultimately the "bottom line", for long periods of time. Employees should be aware in order to try to better respond to negative situations, and prevent personal problems. Labor unions, whose purpose is to represent individuals, could help their members deal with potential negative outcomes of seemingly correct behavior, such as strike participation. As important as striking is at a given time, lingering effects on the health of individuals remains more important.

Hypothesis 4

Hypothesis 4: Strike participation and support will negatively correlate with current job affect and current job satisfaction.

Hypothesis 4 was not supported. Neither job affect nor job satisfaction negatively correlated with strike participation and support. (Job affect and satisfaction were strongly correlated, and both were, in turn, strongly negatively correlated with job stress and all three sub-scales: Quinn and Shepard's (1974) Depressed Mood at Work, Patchen's (1970) Psychological symptoms of 
Stress, and House and Rizzo's (1972) Anxiety-Stress Questionnaire.) The most likely reason for the lack of support for this hypothesis was the time delay mentioned above. Meyer, Allen and Gellatly's (1990) study of commitment and affect illustrates this potential problem well. The positive correlation found between "continuance commitment" and "affective attachment" (p.718) in the cross-sectional portion was not found in the longitudinal study. The longest lag between responses in this true longitudinal study was 11 months. In the present study, there was at least two years between the actual experience of commitment/participation and the responses (which, thus, and in addition, were done in retrospect - another problem, already discussed).

\section{Limitations}

There are realized limitations to this study. There were also anticipated problems that were not manifested. First (in addition to the time-lag issue discussed), there is the problem created by retrospective reports; that is, asking the former employees to recall their participation and feelings/acts of commitment from quite some time ago. Remembering may have been difficult, and the remembrances, themselves, may be flawed solely based upon the time that has elapsed. Furthermore, attitudes may be colored by dissonance reduction (Festinger, 1957). In other words, the participants may have, perhaps 
unknowingly, responded to the scales so as to align their attitudes and opinions with their actions; i.e., cognitively justify their own actions/participation in the ultimately futile situation.

A second recognized limitation is the absence of baseline measures (for these, or similar, participants) on any of the proposed scales. Baseline measures would have helped to detect potential problems related to reliability, dissonance reduction (discussed above), apathy in regard to the survey, and either lack of, or seemingly excessive, attitude change. Another methodological limitation is the inability of correlational data to allow inferences of causality; i.e., it cannot be truly said that strike participation led to current job stress/strain.

Although the issue is controversial (Spector, 1987; Williams, Cote \& Buckley, 1989; Bagozzi \& Yi, 1990), there was the potential for problems of method variance in self-report studies, particularly those measuring affect. Spector's discussion of the risk of "acquiescence" (p.438), the risk of participants either simply agreeing or disagreing with all items is particularly relevant. In regard to the present study, it was thought that participants might not have been willing to put forth the necessary effort for the sake of a study regarding an unfortunate period in their careers. 
This potential problem did not appear. A response rate of approximately $25 \%$ was achieved, with responses appearing to have been given with thought. In fact, many participants attached additional comments, although none were solicited.

Finally, there is the possibility of the data having been flawed by recollections of the organizational climate at Eastern Airlines. Foremost, there is the basic potential problem of apathy that can arise from a poor climate (Kalekin-Fishman, 1986), and could have affected the responses to the questionnaire. This could have led to haphazard answers, large numbers of unanswered items, or unreliable scale outcomes. None of these problems occurred. It is also possible that general perceptions of the organizational climate may have clouded the participants' recollections of their individual commitment, making it difficult to differentiate their separate commitment levels to the organization and to the union. They may, instead, have simply recalled general attitudes about the situation. However, the data do not support this interpretation. The patterns of correlation do not reflect there being any one factor that underlied responses.

It is, additionally, possible that organizational climate may have actually affected the individuals' commitment to the union and/or the organization. Thacker 
and Fields (1987) found, for example, that labormanagement efforts to improve "quality of worklife" (through "QWL interventions") (p.101) affected both perception of the union (given credit for perceived successes) and management (given credit for perceived successes; blamed for perceived failures). Similarly, as discussed earlier, Angle and Perry (1986) found that more positively perceived labor-management climates were associated with higher dual commitment. To a lesser extent, the same relationship was evident for separate union and organizational commitment.

\section{Contributions}

The practical contributions of the study (for management, unions, and individuals) have been described above in each hypothesis section. In addition, the present research adds to the commitment, union, participation, and stress literature in several ways. It contributes to the union participation literature in that we surveyed union participation before, and strike participation/support during a long, intense and unique dispute. Most importantly, the study is the first of its kind to compare unilateral and dual commitment, and to compare the two types of commitment to actual (not theoretical) strike participation. Finally, it analyzed another area in which research is lacking: the later effects of an acutely stressful time-period. 
LIST OF REFERENCES

Ackerley, G. D., Burnell, J., Holder, D. C. \& Kurdek, L. A. (1988). Burnout among licensed psychologists. Professional Psychology: Research and Practice, 19. $624-631$

Angle, H. L., \& Perry, J. L. (1986). Dual commitment and labor-management relationship climates. Academy of Management Journal, 29, 31-50.

Arnhold, R. M. \& Razak, W. N. (1991). Overcoming learned helplessness: Managerial strategies for the 1990's. Journal of Employment Counseling, 28, 99-106. Bagozzi, R. P., \& Yi, Y. (1990). Assessing method variance in multitrait-multimethod matrices: The case of self-reported affect and perceptions at work. Journal of Applied Psychology, 75, 547-560. Barling, J., Wade, B., \& Fullagar, C. (1990). Predicting employee commitment to company and union: Divergent models. Journal of Occupational Psychology, 63, 49-61 Baum, A., Fleming, R., \& Reddy, D. M. (1986). Unemployment stress: Loss of control, reactance and learned helplessness. Social Science and Medicine, 22, 509-516.

Beutell, N. J., \& Biggs, D. L. (1984). Behavioral intentions to join a union: Instrumentality $\mathrm{x}$ valence, locus of control, and strike attitudes. Psychological Reports, 55, 215-222. 
Blyton, P., Nicholson, N., \& Ursell, G. (1981). Job status and white-collar members' union activity. Journal of Occupational Psychology, 54, 33-45. Brief, A. P., Burke, M. J., George, J. M., Robinson, B. S. \& Webster, J. (1988). Should negative affectivity remain anunmeasured variable in the study of job stress? Journal of Applied Psychology, 73, 193-198. Brief, A. P., \& Roberson, L. (1989). Job attitude organization: An exploratory study. Journal of Applied Social Psychology, 19, 717-727.

Burke, M. J., Brief, A. P., \& George, J. M. (1993). The role of negative affectivity in understanding relations between self-reports of stressors and strains: A comment of the applied psychology literature. Journal of Applied Psychology, 78, 402412 .

Chemers, M. M., Hays, R. B., Rhodewalt, F., \& Wysocki, J. (1985). A person-environment analysis of job stress: A contingency model explanation. Journal of Personality and Social Psychology, 49, 628-635. Chen, P. Y., \& Spector, P. E. (1991). Negative affectivity as the underlying cause of correlations between stressors and strains. Journal of Applied Psychology, 76, 398-407. Chrissos, J. (1989, March 5). Pilots put blame on Lorenzo. The Miami Herald, p. 22A. 
Cohen, J. (1969). Statistical power analysis for the behavioral sciences. New York: Academic Press. Conlon, E. J., \& Gallagher, D. G. (1987). Commitment to employer and union: Effects of membership status. Academy of Management Journal, 30, 151-162.

Dailey, R. C., Ickinger, W., \& Coote, E. (1986). Personality role variables as predictors of tension discharge rate in three samples. Human Relations, 39, 991-1004.

Festinger, L. (1957). A theory of cognitive dissonance. Stanford, CA: Stanford University Press. Fiedler, F. E. (1967). A theory of leadership effectiveness. New York: McGraw-Hill. Fields, G. (1989, March 5). Strikers savor the small victories. The Miami Herald, p. 22A.

Friedman, L., \& Harvey, R. J. (1986). Factors of union commitment: The case for a lower dimensionality. Journal of Applied Psychology, 21, 371-376.

Fryxell, G. E., \& Gordon, M. E. (1989). Workplace justice and job satisfaction as predictors of satisfaction with union and management. Academy of Management Journal, 32, 851-866.

Fukami, C. V., \& Larson, E. W. (1984). Commitment to company and union: Parallel models. Journal of Applied Psychology, 69, 367-371. 
Fullagar, C. (1986). A factor analytic study on the validity of a union commitment scale. Journal of Applied Psychology, 71, 129-136.

Fullagar, C., \& Barling, J. (1989). A longitudinal test of a model of the antecedents and consequences of union loyalty. Journal of Applied Psychology, 74, 213227.

Fusilier, M. R., Ganster, D. C., \& Mayes, B. T. (1987). Effects of social support, role stress, and locus of control on health. Journal of Management, 13, 517-528. Gordon, M. E., Philpot, J. W., Burt, R. E., Thompson, C. A., \& Spiller, W. E. (1980). Commitment to the union: Development of a measure and an examination of its correlates. Journal of Applied Psychology, 65, 479499.

Greer, J. G., \& Wethered, C. E. (1984). Learned

helplessness: A piece of the burnout puzzle. Exceptional children, 50, 524-530.

Hackman, J. R., \& Oldham, G. R. (1975). Development of the job diagnostic survey. Journal of Applied Psychology, 60, 159-170.

Hoffman, C. (1978). Empowerment movements and mental health: Locus of control and commitment to the United Farmer Workers. Journal of Community Psychology, 6 , 216-221. 
House, R. J., \& Rizzo, J. R. (1972). Role conflict and ambiguity as critical variables in a model of organizational behavior. Organizational Behavior and Human Performance, 2, 467-505.

Jenner, J. R. (1988). The experience of work stress as a function of stress in a primary relationship. Psychological Reports, 62, 711-717.

Jex, S. M., Beehr, T. A., \& Roberts, C. K. (1992). The meaning of occupational stress items to survey respondents. Journal of Applied Psychology, 77, 623628.

Kalekin-Fishman, D. (1986). Burnout or alienation? A context specific study of occupational fatigue among secondary school teachers. Journal of Research and Development in Education, 19, 24-34.

Kaufmann, G. M., \& Beehr, T. A. (1986). Interactions between job stressors and social support: Some counterintuitive results. Journal of Applied Psychology, 71, 522-526.

Klandermans, B. (1984). Mobilization and participation: Social-psychological expansions of resource mobilization theory. American Sociological Review, 49, $583-600$

Klandermans, B. (1986). Perceived costs and benefits of participation in union action. Personnel Psychology, 39, 379-397. 
Klandermans, B. (1989). Union commitment: Replications and tests in the Dutch context. Journal of Applied Psychology, 74, 869-875.

Kremer, J. F., Fraser, S. L, \& Henzman, D. J. (1987). The relation of stress to personal and work outcomes. Paper presented at the annual conference of the Southeastern Psychological Association, Atlanta, GA. Ladd, R. T. ,

Gordon, M. E., Beauvais, L. L., \& Morgan, R. L. (1982). Union commitment: Replication and extension. Journal of Applied Psychology, 67, 640-644\&

Lyons, D. (1989, March 5). A fight to the finish was inevitable. The Miami Herald, pp. 1A, $20 \mathrm{~A}$. Magenau, J. M., Martin, J. E., \& Peterson, M. M. (1988). Dual and unilateral commitment among stewards and rank-and-file union members. Academy of Management Journal, 31, 359-376.

McGee, G. W., \& Ford, R. C. (1987). Two (or more?)

dimensions of organizational commitment: Reexamination of the affective and continuance commitment scales. Journal of Applied Psychology, 72, 638-641.

McMullen, M. B., \& Krantz, M. (1988). Burnout in day care workers: The effects of learned helplessness and selfesteem. Child and Youth Quarterly, 17, 275-280. Mellor, S. (1990). The relationship between membership decline and union commitment: A field study of local 
unions in crisis. Journal of Applied Psychology, 75, $258-267$.

Meyer, J. P., Allen, N. J., \& Gellatly, I. R. (1990).

Affective and continuance commitment to the

organization: Evaluation of measures and analysis of concurrent and time-lagged relations. Journal of

Applied Psychology, 75, 710-720.

Nelson, D. L., \& Quick, J. C. (1985). Professional women:

Are distress and disease inevitable? Academy of

Management Review, 10, 206-218.

Overmier, J. B., \& Seligman, M. E. P. (1967). Effects of

inescapable shock upon subsequent escape and avoidance

learning. Journal of Comparative and Physiological

Psychology, 63, 23-33.

Owens, D., McNair, J., and Lopez, E. (1991, January 19).

Airline 'family' tearful, dejected. The Miami Herald,

p. 5A.

Patchen, M. (1970). Participation, achievement, and

involvement on the job. Englewood Cliffs, NJ:

Prentice-Hall.

Pauly, D., Calonius, E., Waldman, S. (1989, March 13).

Can Eastern air lines survive? Newsweek, p.42.

Porter, L. W., \& Smith, F. J. (1970). The etiology of

organizational commitment. Unpublished paper,

University California at Irvine. 
Porter, L. W., Steers, R. M., Mowday, R. T., \& Boulian, P. V. (1974). Organizational commitment, job satisfaction, and turnover among psychiatric technicians. Journal of Applied Psychology, 59, 603609 .

Quinn, R. P., \& Shepard, L. J. (1974). The 1972-73 Quality of Employment Survey. Ann Arbor, Michigan: University of MI, Institute for Social Research. Reed, T. (1991, January 19). Eastern folds its wings. The Miami Herald, pp. 1A, $4 \mathrm{~A}$.

Schriesheim, C. A. (1978). Job satisfaction, attitudes toward unions, and voting in a union representation election. Journal of Applied Psychology, 63, 548-552. Schwartz, J., Calonius, E., Gonzalez, D. L., Gibney, Jr., F. (1989, March 20). A boss they love to hate. Newsweek, pp. 20-24.

Seligman, M. E. P., \& Schulman, P. (1986). Explanatory style as a predictor of productivity and quitting among life insurance sales agents. Journal of Personality and Social Psychology, 50, 832-838. Spector, P. E. (1987). Method variance as an arifact in self-reported affect and perceptions at work: Myth or significant problem? Journal of Applied Psychology, 72, $438-443$. 
Staff. (1989, March 13). Union solidarity stuns Eastern, strands thousands of passengers. Aviation Week and Space Technology, p. 19.

Stagner, R., \& Eflal, B. (1982). Internal union dynamics during a strike: A quasi-experimental study. Journal of Applied Psychology, 67, 37-44.

Summers, T. P., Betton, J. H., \& DeCotiis, T. A. (1986). Voting for and against unions: A decision model. Academy of Management Review, 11, 643-655. Sutton, R., \& Kahn, R. L. (1986). Prediction, understanding, control as antidotes to organizational stress. In J. Lorsch (Ed.), Handbook of organizational behavior. Englewood cliffs, NJ: Prentice-Hall.

Tetrick, L. E., \& LaRocco, J. M. (1987). Understanding, prediction, and control as moderators of the relationships between perceived stress, satisfaction, and psychological well-being. Journal of Applied Psychology, 72, 538-543. Tetrick, L. E., Thacker, J. W., \& Fields, M. W. (1989). Evidence for the stability of the four dimensions of the commitment to the union scale. Journal of Applied Psychology, 74, 819-822.

Thacker, J. W., \& Fields, M. W. (1987). Union involvement in quality-of-worklife efforts: A longitudinal investigation. Personnel Psychology, 40, 97-111. 
Thacker, J.W., Fields, M. W., \& Barclay, L. A. (1990). Union commitment: An examination of antecedent and outcome factors. Journal of Occupational Psychology, $63,33-48$

Thacker, J. W., Fields, M. W., \& Tetrick, L. E. (1989). The factor structure of union commitment: An application of confirmatory factor anlaysis. Journal of Applied Psychology, 74, 228-232.

Walker, J. L, Walker, L. S., \& MacLennan, P. M. (1986). An informal look at farm stress. Psychological Reports, 59, 427-430.

Watson, D., \& Tellegen, A. (1985). Toward a consensual structure of mood. Psychological Bulletin, 98, 219235.

Williams, L. J., Cote, J. A., \& Buckley, M. R. (1989). Lack of method variance in self-reported affect and perceptions at work; Reality or artifact? Journal of Applied Psychology, 24, 462-468.

Williams, L. J., \& Hazer, J. T. (1986). Antecedents and consequences of satisfaction and commitment in turnover models: A reanalysis using latent variable structural equation methods. Journal of Applied Psychology, 71, 219-231.

wood, C. J. (1980). Learned helplessness: A factor in counseling displaced homemakers. Journal of Employment Counseling, 26, 4-10. 
APPENDIX 
Appendix

\section{Union Participation scale}

1) How would you characterize your voting/participation in union elections? (1-Not at all active: 2 -slightly active:

3-Somewhat active; 4-very active; 5-Extremely active)

2) How often did you attend union meetings? (1-Never; 2-Rarely; 3-Sometimes; 4-often; 5-Nearly all the time)

3) How familiar were/are you with the provisions of the Agreement your union held with Eastern Airlines? (1Unfamiliar; 2-Know very little; 3-know somewhat; 4-Know a lot: 5-know almost everything)

4) How often did you file grievances, or were you involved with the filing of grievances? (1-Never: 2Rarely; 3-Sometimes; 4-Frequently; 5-Very often)

5) How often did you serve as a union elected official or serve on a union committee? (1-Never; 2-Rarely; 3Sometimes; 4-often; 5-Nearly all the time)

6) How often did you read union publications? (1-Never; 2-Rarely; 3-Sometimes; 4-Often; 5-Nearly all the time) 7) Overall, how much time would you say you devoted to the union? (1-Much less than average; 2-Below average: 3-Average; 4-Above average; 5-Well above average) 8) How supportive were you of the union's activities? (1Not at all supportive; 2-Slightly supportive; 3-Somewhat supportive; 4-Very supportive; 5-Extremely supportive) 


\section{Strike Participation and support scale}

1) How did you feel about beginning the strike prior to its starting? (1-very much against: 2-Somewhat against; 3-Neutral; 4-Somewhat in favor: 5-very much in favor)

2) As the strike progressed, how did you feel about it? (1-Very much against; 2-Somewhat against; 3-Neutral;

4-Somewhat in favor: 5-very much in favor)

3) During the strike, how often did you participate in strike-related activities? (1-Never; 2 -Rarely; 3Sometimes; 4-Often: 5-Nearly all the time)

4) Did you request, or get involved with the disbursement of, union financial assistance during the strike? (1-Not at all; 2-Slightly involved; 3-Was unaware of program; 4Fairly involved; 5-Very involved)

5) Now that you have seen the outcome, do you agree that the unions should have taken the course they took beginning in March, 1989? (1-strongly disagree; 2Disagree somewhat; 3-Neutral; 4-Agree somewhat: 5Strongly agree)

6) Having been through this experience, how do you feel about joining a union in the future/becoming involved in another company with a strong union presence? (1Definitely would not; 2 -Probably would not; 3 -Neutral; 4Probably would: 5-Definitely would)

Miscellaneous ouestions

1) Were you a union member? (Yes, No) 
2) Were you newly hired after March, 1989? (Yes, No) (If yes, please skip to question \#8.)

3) Did you strike with your union? (Yes, No) (If no, please skip to question \#7.)

4) If you did strike, did you return to work? (Yes, No)

5) For members of TWU, ALPA, did you return to work prior to, or at the time of, the union/management reaching a back-to-work agreement? (Prior to, At time of, Did not return to work)

6) When Eastern declared bankruptcy, were you? (Much more resolved to strike, somewhat more resolved to strike, Made no difference, Somewhat less resolved to strike, Much less resolved to strike)

7) If you could return to March, 1989, would you take the same actions that you did in regard to striking? (Yes, No) in regard to returning to work? (Yes, No)

8) Are you/will you be pursuing employment in the airline industry? (Yes, No)

9) Do you feel you will need to relocate, or have you already done so? (Yes, No) If so, where? (Out of Miami, out of South Florida, out of Florida)

10) Did you make any preparations for other employment prior to Eastern closing in January, 1991? (Yes, No) If so, what kind? (Developing contacts, seeking further/additional education and/or training, Gathering applications and/or information about other employment 
opportunities, other-please describe)

11) What was your last position with Eastern Airlines?

12) How long did you hold that position? (Years, Months)

13) How long did you work for Eastern? (Years, Months)

14) How long have you worked in the airline industry? (Years, Months)

15) Are you presently employed? (Yes, No)

16) If presently employed, what is your current occupation?

17) If presently employed, how difficult was it to find your new job? (Not difficult at all, slightly difficult, Neutral, Fairly difficult, very difficult)

18) If presently employed, how do you consider your new job in relation to your job at Eastern, overall? (New job is much worse, New job is somewhat worse, Neutral, New job is somewhat better, New job is much better)

\section{Demographic Questions}

1) Are you married? (Yes, No) If so, did your spouse also work for Eastern? (Yes, No)

2) Do you have children? (Yes, No) If so, how many? Are any of your children under the age of 18?

3) Do you own a home? (Yes, No)

4) Besides a mortgage, do you have any other large monthly payments (i.e., cars, boats)? (Yes, No)

5) What was your approximate combined household income while working at Eastern? 
6) What is your approximate combined household income presently?

7) What is your age?

8) Are you male or female?

9) What is the highest level of education you have completed? (0-11th grade, Graduated high school, some college, Associate degree, Bachelor degree, some graduate work, Graduate degree)

10) With which ethnic group do you identify? (White, Black, Hispanic, Asian, American Indian, Other-please specify) 